\author{
Anna Skibińska* \\ ORCID: 0000-0002-6097-2122 \\ Uniwersytet Wrocławski
}

\title{
RATUNEK DLA GOSPODARKI \\ CZY ZAGROŻENIE ZE WSCHODU? \\ UKRAIŃCY W NAGŁÓWKACH „GAZETY WROCŁAWSKIEJ”
}

\begin{abstract}
Celem artykułu było zbadanie, w jaki sposób regionalny portal internetowy opowiada o ukraińskich migrantach mieszkających na Dolnym Śląsku. Przedmiot badań stanowiły nagłówki artykułów prasowych z leksemem „Ukrainiec” opublikowane na portalu www.gazetawroclawska.pl w roku 2019. Dotychczasowe badania dotyczące językowego obrazu Ukraińca w języku polskim pokazywały, że relacje polsko-ukraińskie są silnie uwarunkowane historycznie oraz często wpisywane w trójczłonową opozycję: Obcy - Inny - Swój. W trakcie przeprowadzonej analizy zawartości zgromadzonego materiału badawczego zdekodowano typowe konstrukcje nagłówków, zapowiadające teksty o Ukraińcach na portalu internetowym „Gazety Wrocławskiej”. Określono dominujące funkcje nagłówków, wykorzystywane środki językowe, lematy z najwyższą frekwencją oraz stereotypy. Nawiązując do problematyki swojskości i obcości oraz dostrzegając w analizowanych wypowiedziach medialnych etnostereotypy na temat Ukraińców, zrekonstruowano zróżnicowany wizerunek migrantów z Ukrainy - przedstawianych jako ofiary, zagrożenie, ale i szansa.
\end{abstract}

Słowa kluczowe: wizerunek, obcość, „Gazeta Wrocławska”, nagłówek, swojskość, Ukraińcy

\section{WPROWADZENIE}

Rozmaite opozycje zdają się dzisiaj jednym z podstawowych elementów budujących medialne przekazy. Sprzeczne interesy czy rozbieżne poglądy stają się jeszcze wyraźniejsze, kiedy spoglądamy na rzeczywistość przez medialne zwierciadło. Dziennikarskie narracje mają potencjał antagonizowania wybranych grup, a ich rola - za sprawą chociażby mnogości komunikatów oraz szerokiej dostępności treści - jest dziś niezwykle istotna. Chcąc przyciągnąć uwagę odbiorców, media chętnie sięgają po zagadnienia konfliktowe, niekiedy wręcz kreują spory bądź uwypuklają je, co dostrzec można zwłaszcza w „krzyczących” nagłówkach (por. Dobek-Ostrowska, 2009; Piekot, 2006).

* Anna Skibińska, Kolegium Doktorskie Wydziału Filologicznego, Uniwersytet Wrocławski, pl. Biskupa Nankiera 15b, 50-140 Wrocław, Polska; e-mail: anna.skibinska@uwr.edu.pl 
Warto dodać, że współczesna „konsumpcja mediów” bywa nader pospieszna i bezrefleksyjna. Wartość informacyjna zdominowana jest nierzadko przez rozrywkową formę, trywializującą przedstawiane zagadnienia (por. infotainment - Nowak, 2009). Ponadto, przestrzeń internetu oraz logika sprzedaży newsów na rynku, na którym toczy się zacięta walka o uwagę odbiorców, inspirować mogą dziennikarzy do tworzenia sensacyjnych, szokujących nagłówków. Jeśli skłonią one czytelnika do kliknięcia w hiperlink i spędzenia kilku kolejnych sekund na danym portalu ${ }^{1}$, to pozycja witryny przy negocjacjach z reklamodawcami ma szansę się poprawić (por. zjawisko clickbaitowania - Lisowska-Magdziarz, 2019). Badacze, analizujący współczesną przestrzeń mediów, zwracają również uwagę na medialne bańki (ang. filter bubble), które zawężają perspektywę odbioru rzeczywistości (mogą utrwalać uprzedzenia, pogłębiać podziały), choć w zamian oferują m.in. poczucie bezpieczeństwa (Malinowski, 2016).

Powyższe spostrzeżenia zachęcają do refleksji na temat medialnego wizerunku Ukraińców, kształtowanego w nagłówkach przez dziennikarzy portalu internetowego „Gazety Wrocławskiej”. Problematyka stosunku do Innego czy Obcego cieszy się sporym zainteresowaniem badaczy (por. m.in. Benedyktowicz, 2000; Guzik, 2008; Znaniecki, 1990, a także (Rozbicka, 2020; oraz przywołana tam literatura). Jak pisze Barbara Guzik: „Kategorie obcości i swojskości należą do kategorii antropologicznych, są wspólne dla wszystkich społeczności mających kontakty z innymi i służą strukturalizacji świata. [...] dychotomia swój-obcy wzajemnie się dopełnia, tworząc całościowy obraz rzeczywistości społecznej w modelu świata" (2008, s. 36).

Obcym jest ten, kto później dołączył do danej zbiorowości i wniósł do niej odrębne wartości kulturowe. Florian Znaniecki twierdził z kolei, że obcość to kategoria relatywna, zawsze bowiem jest się obcym wobec jakiejś zbiorowości lub jednostki. Już samo zetknięcie się z grupą, którą charakteryzują inne społeczne wartości, przyczynia się do doświadczania obcości (1990, s. 230). Co ważne, relacje między dystansem a bliskością, swojskością a obcością przejawiać się mogą zarówno w sytuacjach codziennych, jak i w medialnych narracjach. Często łączą się one z uproszczonym przeciwstawnym wartościowaniem: swój-dobry vs obcy-zły (por. semantyka aksjologiczna - Krzeszowski, 1999, s. 18).

\section{MEDIALNY WIZERUNEK UKRAIŃCÓW - DOTYCHCZASOWY STAN BADAŃ}

Chociaż trudno nie dostrzec roli, jaką media mogą odgrywać w reprodukowaniu oraz w legitymizowaniu rozmaitych obrazów świata, to jak dotą $\mathrm{d}^{2}$ nie ukazała się żadna praca przedstawiająca wyniki badań nad aktualnym medialnym obrazem „Obcych zza Buga”, wynikającym z nagłówków polskojęzycznych witryn regionalnych. Tematyka współczesnej migracji z Ukrainy cieszyła się dotychczas głównie zainteresowaniem socjologów oraz

\footnotetext{
1 W niniejszym artykule zamiennie stosuje się terminy: portal internetowy, serwis internetowy, witryna internetowa. Autorka, będąc świadoma różnic, jakie wskazywane są w literaturze przedmiotu między tymi pojęciami, uznaje jednak, że źródło doboru korpusu spełnia jednocześnie definicyjne wymogi określone dla każdego z trzech powyższych pojęć - o problemach definicyjnych nowych mediów zob. także (Cyrek, 2020).

2 Stan na dzień 31.05.2021 r.
} 
politologów (por. Grzymała-Kazłowska, 2007; Jurek, 2019; Konieczna-Sałamatin, 2001; Lubicz Miszewski, 2018), a medioznawcy skupiali się na analizie przekazów telewizyjnych, wpisów na forach internetowych oraz komunikatów w mediach społecznościowych (por. Cymanow-Sosin i Drąg, 2017; Golińska-Konecko, 2020; Radzka, 2006; Rozbicka, 2018; Troszyński, 2016, 2018).

Dotychczasowe badania dotyczące językowego obrazu Ukraińca w języku polskim obejmowały między innymi analizę materiałów Narodowego Korpusu Języka Polskiego z lat 2005-2010 (Borkowska, 2020), eksplorację artykułów o tematyce ukraińskiej z lat 2006-2018 w elektronicznej prasie regionalnej na Dolnym Śląsku (Skibińska, 2020a), a także próbę „zrekonstruowania wyobrażeń, ocen, sądów Polaków o Ukraińcach oraz przedstawienia językowego obrazu naszego wschodniego sąsiada w okresie międzywojnia (1918-1939)" (Sojka-Masztalerz, 2004, s. 7). Przytoczone wyżej analizy prowadzą do kilku podstawowych wniosków.

Po pierwsze, relacje polsko-ukraińskie są silnie „obciążone historycznie” (Sojka-Masztalerz, 2004, s. 4). Kontakty między sąsiednimi narodami mają długą i bogatą historię, a wiele wydarzeń z przeszłości wciąż budzi silne (głównie negatywne - por. Jura i Kałużyńska, 2015, s. 145) emocje. To zaś sprawia, iż medialne wzmianki na temat Ukraińców często odwołują się do etnostereotypów (por. Prokop, 2013; Bielecka-Prus, 2020; Skibińska, 2020b). Zagadnienie stereotypizacji zostanie szerzej opisane w dalszej części artykułu, ale już teraz warto wspomnieć o raportach publikowanych przez Centrum Badania Opinii Społecznej, przedstawiających aktualny stosunek Polaków do innych narodów (w tym m.in. do Ukraińców - por. Omyła-Rudzka, 2021).

Po drugie, medialne wizerunki Ukraińców są często wpisywane w trójczłonową opozycję: Obcy - Inny - Swój, a jako uzasadnienie dla tej opozycji badacze wskazują przede wszystkim systemy wartości oraz aktualne warunki polityczne lub kulturowe (Sojka-Masztalerz, 2004, s. 191-194; Borkowska, 2020, s. 96-98). Co istotne, wspomniane okoliczności mogą ulegać zmianom, a tym samym także medialne przekazy bywają zróżnicowane i zmienne w czasie. $Z$ dotychczasowych ustaleń wynika, że kiedy dotyczą one wydarzeń sportowych, są zazwyczaj neutralne (nie mają nacechowania emocjonalnego), negatywna waloryzacja wiąże się natomiast głównie z kontekstem historycznym (por. Baran, 2016; Borkowska, 2020; Jura i Kałużyńska, 2015).

Należy jednak podkreślić, że w literaturze przedmiotu można dostrzec też pewne rozbieżności w opisie Ukraińców. Przyczyniają się do nich przede wszystkim odmienne źródła danych (dzienniki, tygodniki, portale informacyjne, media społecznościowe), niepokrywające się okresy badawcze oraz różne metodologie badań. Dlatego za uzasadnione uznano wypełnienie dostrzeżonej luki badawczej za pomocą analizy zawartości nagłówków opublikowanych na portalu www.gazetawroclawska.pl w roku 2019. Okres ten wybrano z uwagi na chęć objęcia badaniem całego roku kalendarzowego, w którym występują zarówno planowane uroczystości państwowe, święta czy rocznice, jak i zdarzenia nieprzewidywalne. Tak oznaczone cezury czasowe miały także pomóc w dostrzeżeniu potencjalnych zmian narracji ${ }^{3}$, zachodzących

3 Pojęcie narracji rozumiane jest w niniejszym artykule jako ogół publikacji, tworzących medialną opowieść na wskazany temat. 
w poszczególnych miesiącach. Dodatkowo był to najbardziej aktualny przedpandemiczny rok, a zdaniem autorki analiza przekazów medialnych dotyczących migrantów podczas pandemii COVID-19 zasługiwałaby na osobne studium.

Do zawężenia poszukiwań do wskazanego portalu skłaniał między innymi jego szeroki zasięg$^{4}$, a także potwierdzona w raporcie Instytutu Monitorowania Mediów (dalej: IMM), opiniotwórczość - „Gazeta Wrocławska” to dzisiaj największy regionalny dziennik na Dolnym Śląsku ${ }^{5}$. Chociaż papierowy dziennik oraz portal internetowy o tym samym tytule to dwa odrębne media, to jednak z obserwacji autorki wynika, że dziennikarze zatrudnieni w rzeczonej redakcji przygotowują publikacje jednocześnie dla obu mediów. Niemniej, z uwagi na ograniczone miejsce, w dzienniku drukowane są jedynie najważniejsze teksty i zdjęcia, podczas gdy informacje na portalu są nieustannie aktualizowane i jest ich więcej (por. pojęcie „multimedialnego kombajnu” - Szynol, 2014).

Wspomniane powiązania potwierdzają również informacje ze strony internetowej PPG. Po kliknięciu w link https://polskapress.pl/pl/portfolio/internet/informacyjne/gazeta-wroclawska trafiamy dokładnie na tę samą stronę internetową, jak po kliknięciu w link https://polskapress. $\mathrm{pl} / \mathrm{pl} /$ portfolio/prasa/dzienniki/polska-gazeta-wroclawska znajdziemy tam zarówno opis dziennika regionalnego, jak i serwisu www.gazetawroclawska.pl. Biorąc pod uwagę powyższe, za uzasadnione uznano przytoczenie statystyk IMM właściwych dla dziennika, choć to internetowe nagłówki stanowiły przedmiot prezentowanych tu badań.

Przegląd wydań drukowanych „Gazety Wrocławskiej” pozwala stwierdzić, że w 2019 roku jedynie dwa artykuły o Ukraińcach znalazły się na pierwszej stronie (2 kwietnia tekst zatytułowany „Ile zarabiają Ukraińcy w Polsce?” oraz 20 listopada - „Tysiące Ukraińców wyjedzie w 2020 roku z Polski do Niemiec? Jest takie zagrożenie”). Oprócz tego dziesięć publikacji mogliśmy odnaleźć na dalszych stronach gazety. Ich tematyka skupiała się wokół spraw pracowniczych oraz obaw przed wyjazdem Ukraińców z Polski (por. 14 czerwca - „Ukraińcy potrzebni, ale mamy własne rezerwy. Rozmowa”, 13 października - „Ukraińcy powoli żegnają się z Polską. Jadą na zachód”, 14 listopada - „Brak pracowników z Ukrainy coraz częściej spędza sen z powiek połowie szefów firm”). Podsumowując, zarówno niewielka liczba artykułów dotyczących Ukraińców, jak i ich monotematyczność prowadzi do wniosku o mniejszej ekspozycji zagadnień związanych z migrantami zza Buga w wydaniu drukowanym aniżeli na portalu internetowym. Powyższa konstatacja stanowi kolejne uzasadnienie dla źródła doboru materiału badawczego.

Dodajmy, że ważnym aspektem była wyraźna obecność ukraińskich migrantów w przestrzeni Dolnego Śląska w 2019 roku. Należy podkreślić, że w latach 2015-2019 liczba Ukraińców pracujących legalnie w Polsce wzrosła trzynastokrotnie. W rezultacie w 2019 roku składki do Zakładu Ubezpieczeń Społecznych wpłacało ponad 450 tysięcy Ukraińców6, z czego 49 tysięcy pracowało na Dolnym Śląsku7. Co istotne, utrzymuje się tutaj wyraźny

4 Por. https://gazetawroclawska.pl/rekordowy-miesiac-portalu-gazetawroclawskapl/ar/13258527 [31.05.2021].

5 Por. https://gazetawroclawska.pl/gazeta-wroclawska-jednym-z-najbardziej-opiniotworczych-mediow/ar/c114649817 [31.05.2021].

6 Por. https://wroclaw.tvp.pl/44048556/rosnie-liczba-obcokrajowcow-na-dolnym-slasku [31.05.2021].

7 Por. https://www.tuwroclaw.com/wiadomosci,dolny-slask-zaglebiem-pracownikow-z-ukrainy,wia5-3273-50455. html [31.05.2021]. 
trend rosnący, w ciągu roku liczba pracujących Ukraińców wzrosła bowiem w województwie dolnośląskim o 10 tysięcy $^{8}$. Dodatkowo warto nadmienić, że ukraińską migrację na Dolny Śląsk wyróżnia osiadły charakter, dobre wykształcenie przyjezdnych oraz stosunkowo korzystna sytuacja na rynku pracy (Górny et al., 2019, s. 53-58).

Podsumowując, celem niniejszych badań będzie określenie, jaki obraz Ukraińców wynikał z przedpandemicznej narracji „Gazety Wrocławskiej”. Studium przypadku obejmie nagłówki opublikowane w 2019 roku na jej internetowym portalu.

\section{METODA I ZAKRES BADAŃ}

„Gazeta Wrocławska” to redakcja wchodząca w skład Polski Press Grupy (dalej: PPG). Historia dziennika regionalnego sięga czasów powojennych - gazeta, zwana wówczas „Gazetą Robotniczą”, była organem Komitetu Wojewódzkiego Polskiej Zjednoczonej Partii Robotniczej. Po prywatyzacji w 1990 roku przeistoczyła się najpierw w „Robotniczą Gazetę Wrocławską”, po czym z jej nazwy usunięto określenie „robotnicza”, budzące negatywne skojarzenia z polityczną przeszłością. W 2004 roku gazeta należąca do niemieckiego holdingu Verlagsgruppe Passau przejęła dwie konkurencyjne wrocławskie redakcje: „Słowo Polskie” oraz „Wieczór Wrocławia”. Kolejne lata były okresem dalszej ekspansji rynkowej spółki w jej portfolio znajduje się obecnie 20 dzienników regionalnych, niemal 120 tygodników lokalnych, kilka magazynów, dodatki telewizyjne oraz 23 regionalne serwisy informacyjne.

PPG jest liderem na rynku prasy lokalnej i regionalnej, jej serwisy odwiedza średnio 2,8 mln internautów dziennie. Co jednak istotne, stosunkowo krótki jest średni czas, podczas którego użytkownicy przebywają na stronach PPG - wynosi on około 3,5 minuty9 . Pozwala to przypuszczać, że część odwiedzających nie zapoznaje się wnikliwie z treścią artykułów, lecz jedynie przegląda nagłówki. Ponadto hiperłącza do nagłówków udostępniane są również w mediach społecznościowych, a ich pospieszna konsumpcja (bez wglądu w całą treść dziennikarskiego przekazu) przyczyniać się może do utrwalania stereotypów (por. uwagi na temat „kuszących nagłówków” w dobie postprawdy - Brenda-Mańkowska, 2019). W tym kontekście jeszcze bardziej uzasadnione wydaje się zbadanie właśnie tego elementu przekazu.

Kryterium decydującym o kwalifikacji wybranego nagłówka do dalszych badan był występujący w wypowiedzi medialnej leksem ${ }^{10}$ „Ukrainiec”. Do zebrania odpowiednich

8 Por. https://dziennik.walbrzych.pl/obcokrajowcy-coraz-czesciej-pracuja-leganie-na-dolnym-slasku-ponad70-tysiecy-cudzoziemcow-zarejestrowanych-w-zus-najwiecej-ukraincow/ oraz https://www.nj24.pl/article/ ukraincy-wrocili [31.05.2021].

9 Por. https://www.gemius.pl/wszystkie-artykuly-aktualnosci/wyniki-badania-gemiuspbi-za-luty-2019.html [31.05.2021].

10 „Leksem” rozumiany jest w niniejszym artykule jako „wyraz lub wyrażenie traktowane jako jednostka słownikowa; wyraz słownikowy; na leksem składają się: określone znaczenie leksykalne, zespół wszystkich funkcji gramatycznej oraz ogół form językowych reprezentujących w tekście 1. w jego poszczególnych funkcjach" (https://encyklopedia.pwn.pl/haslo/leksem;3931450.html [19.06.2021]); np. polskie formy: Ukrainiec, Ukraińca, Ukraińcowi, Ukraińcem, Ukraińcu reprezentują leksem „Ukrainiec” w jego pięciu różnych funkcjach gramatycznych. Wszystkie te formy kwalifikowane były do korpusu badawczego. 
tekstów w przeglądarce Google Chrome wykorzystano wtyczkę MozBar. Do wyboru przeglądarki Google Chrome jako źródła pozyskiwania danych na temat publikacji portalu www.gazetawroclawska.pl skłaniała jej popularność w Polsce (około 52-56\% udziałów w 2019 roku, z przewagą nad drugim, Firefoxem, w przypadku komputerów stacjonarnych o około 20-30 punktów procentowych oraz około 70-84\% udziału wśród urządzeń mobilnych ${ }^{11}$ ). Jako niewielkie oceniono ryzyko niezindeksowania stron popularnego portalu informacyjnego w przeglądarce Google Chrome.

Wtyczkę MozBar uznano natomiast za narzędzie dające możliwie najbardziej rzetelne wyniki. Wtyczka ta pozwala między innymi na tworzenie niestandardowych wyszukiwań, odnajdywanie słów kluczowych na stronach internetowych, jak również eksport szczegółów analizy strony wyników wyszukiwania (SERP) do pliku CSV ${ }^{12}$. Dążąc do maksymalnego zobiektywizowania uzyskiwanych rekordów, przed rozpoczęciem poszukiwań wyłączono wyniki osobiste, a sam proces wyszukiwania powtórzono kilkakrotnie na dwóch urządzeniach. Skorzystano z opcji ,wyszukiwanie zaawansowane”, zawężając wyniki do roku 2019, do języka polskiego, do regionu Polski oraz do witryny www.gazetawroclawska.pl. W dowolnym miejscu strony poszukiwano któregoś z następujących słów: Ukrainiec, Ukraińca, Ukrainca ${ }^{13}$, Ukraińcowi, Ukraincowi, Ukraińcem, Ukraincem, Ukraińcu, Ukraincu ${ }^{14}$. Po uruchomieniu wtyczki MozBar i przeprowadzeniu wyszukiwania dla każdej strony wyników wygenerowano plik CSV zawierający wszystkie rekordy odpowiadające sformułowanemu zapytaniu. Następnie wyeksportowany plik sprawdzono ręcznie, usuwając powtarzające się teksty oraz teksty nierelewantne z punktu widzenia celu badań (np. takie, w których leksem „Ukrainiec” pojawiał się jedynie wśród rekomendowanych artykułów bądź w ogłoszeniach). W rezultacie materiał badawczy stanowiła baza danych (w formie arkusza kalkulacyjnego) z 69 rekordami. Na koniec warto dodać, że do uzyskania całkowitej pewności, iż podczas tak przeprowadzonej procedury uzyskano wszystkie relewantne wyniki, pomocne byłoby skorzystanie z danych instytucji archiwizującej zawartość krajowych stron internetowych. Tego typu instytucja nie istnieje jednak przy Bibliotece Narodowej, dlatego spośród dostępnych narzędzi to właśnie wtyczka MozBar, powiązana z danymi gromadzonymi przez najpopularniejszą przeglądarkę Google Chrome, wydała się autorce najbardziej odpowiednia.

Jako technikę badawczą wybrano analizę zawartości (dalej: AZ), której początki odnajdujemy w Polsce w latach 80 . w twórczości Walerego Pisarka. Odwołajmy się zatem do szerokiej definicji AZ sformułowanej przez tego prasoznawcę: „Analiza zawartości jest zespołem różnych technik systematycznego badania strumieni lub zbiorów przekazów, polegającego na możliwie obiektywnym (w praktyce zwykle: intersubiektywnie zgodnym)

11 Por. https://antyweb.pl/top-5-najpopularniejszych-przegladarek/ [19.06.2021].

12 Por. https://chrome.google.com/webstore/detail/mozbar/eakacpaijcpapndcfffdgphdiccmpknp?hl=pl_PL [31.05.2021]. Za pomoc w pobraniu danych autorka pragnie podziękować mgr. Tomaszowi Dziurdzi.

13 Celowe pominięcie znaku diakrytycznego, które zdarza się dość często w pospiesznej komunikacji internetowej.

14 Warto zaznaczyć, że wskazana w tekście pełna lista słów kluczowych nie obejmuje słowa „Ukrainka”. Celem badań było bowiem określenie medialnego wizerunku Ukraińców (mężczyzn posiadających obywatelstwo ukraińskie) na wybranym portalu. Zdaniem autorki wnikliwe zbadanie wizerunku Ukrainek wymagałoby odrębnego studium. 
wyróżnianiu i identyfikowaniu ich możliwie jednoznacznie skonkretyzowanych, formalnych lub treściowych elementów i na głównie porównawczym wnioskowaniu, a zmierzającego przez poznanie zawartości przekazów do poznania innych elementów i uwarunkowań procesu komunikacyjnego" (Pisarek, 1983, s. 45).

Tomasz Gackowski podkreśla, że: „Badanie przekazów, zestawianie i korelowanie ich za pomocą metod analizy zawartości pozwala skutecznie opisać rzeczywistość medialną, która w sposób niezwykle ekspansywny pretenduje do miana rzeczywistości obiektywnej (nie-medialnej, realnej)" (Gackowski, 2009, s. 11).

Atrybuty wyróżniające AZ to między innymi: systematyczność, powtarzalność, wiarygodność, jawność, testowalność hipotez badawczych oraz aprioryczność klucza analizy (Balcerzak i Gackowski, 2009, s. 22-25). Dobór próby determinują natomiast trzy podstawowe zasady: wyczerpania, homogeniczności oraz reprezentatywności (Maj, 2013, s. 134). Warto zaznaczyć, że: „Analiza zawartości bierze pod uwagę nie tylko cechy samej treści, lecz także formy przekazu, takie jak jego kompozycja, struktura oraz sposób, w jaki dana treść została przekazana, wypowiedziana czy wyeksponowana w druku" (Maj, 2013, s. 127).

Podstawowe pytania badawcze, na jakie z pomocą przygotowanego klucza kategoryzacyjnego, poszukiwano odpowiedzi, brzmiały następująco:

1. Jaki był miesięczny rozkład liczby nagłówków z leksemem „Ukrainiec” w 2019 roku?

2. Jaka była przeciętna długość nagłówków (liczba znaków ze spacjami)?

3. Jakie zasadnicze funkcje spełniały analizowane nagłówki?

4. Jaka tematyka dominowała w nagłówkach?

5. Jakie środki językowe się w nich pojawiały?

6. Jakie lematy miały najwyższą frekwencję?

7. Czy nagłówki miały charakter stereotypowy? Jeśli tak, to do jakich stereotypów nawiązywały?

Podczas opracowywania materiału badawczego dążono przede wszystkim do porównania konstrukcji nagłówków, a w rezultacie do stworzenia syntezy. Skorzystano również z aplikacji webowej korpusomat ${ }^{15}$ (Kieraś et al., 2018, s. 21-27), która pozwoliła wygenerować pomocne dane statystyczne, m.in. na temat frekwencji lematów.

Puentując te wstępne rozważania, warto zaznaczyć, iż w niniejszym artykule sięgnięto po szeroką definicję nagłówka, uznając, że jest nim zarówno tytuł, jak i podtytuł (por. Furman, 2006, s. 127, 225). Takie podejście było istotne m.in. ze względu na dostrzeżoną na portalu „Gazety Wrocławskiej” powszechność nagłówków składających się z dwóch wypowiedzeń oraz dążenie do całościowej analizy tych treści, które odbiorca dostrzega zaraz po wejściu na stronę internetową. W materiale badawczym odnotowano 48 nagłówków, zbudowanych z dwóch części (tj. ok. 70\%), dlatego uznano, że to właśnie szeroka definicja przedmiotu badań będzie najbardziej adekwatna, zważywszy na cel wyartykułowany powyżej.

15 Aplikacja ta łączy narzędzia stworzone w Zespole Inżynierii Lingwistycznej Instytutu Podstaw Informatyki PAN - szczegółowy wykaz narzędzi: https://korpusomat.pl/overview [31.05.2021]. 
Doniosła rola spełniana przez nagłówek tekstu prasowego to temat szeroko opracowany w literaturze przedmiotu (por. Pisarek, 1967; Sadowska, 2007; Ślawska, 2008; Pałuszyńska, 2016). Jest to jeden z najmniejszych tekstów dziennikarskich i trudno znaleźć wypowiedź dziennikarską, która byłaby go pozbawiona - nagłówek pełni funkcje strategiczne, skupiając uwagę odbiorcy, jednocześnie w pewien sposób ukierunkowuje dalszą lekturę.

,[...] Wymaga się więc od tytułu, aby był funkcjonalny i stanowił całość z materiałem dziennikarskim, dla którego jest »etykietkąu" (Ślawska, 2008, s. 117).

Walery Pisarek podzielił tytuły na informacyjne oraz publicystyczne (1967, s. 108-109), jednak późniejsi badacze zwracali uwagę na to, że już samo nadanie wiadomości jakiegoś tytułu nie jest zwykle wolne od wartościowania (dlatego trudno mówić o czysto obiektywnym, informacyjnym tytule). Współczesne tytuły przybierają często formę rozrywkową, stanowią rodzaj gry z czytelnikiem (por. infotainment - Nowak, 2009).

Trzy zasadnicze funkcje, jakie według Magdaleny Ślawskiej spełniać może tytuł, to: funkcja nominatywna (nazywająca), deskryptywna (opisująca, streszczająca) oraz pragmatyczna (perswazyjna, ekspresywna) (2008, s. 125). Z kolei Agnieszka Sadowska dzieli tytuły ze względu na pełnione funkcje nieco bardziej szczegółowo na te: o charakterze informującym, przybierające formę pytań retorycznych, wywołujące u odbiorcy żywą reakcję, szok, zmuszające do zajęcia jakiegoś stanowiska, intrygujące, enigmatyczne, niedopowiedzenia oraz alarmujące. Innym kryterium podziału tytułów są względy składniowe, stylistyczne i leksykalne (Sadowska, 2007, s. 403-413). W niniejszym artykule skorzystano z typologii funkcji nagłówków autorstwa Joanny Szylko-Kwas, uznając, że jest ona najbardziej adekwatna dla nagłówków publikowanych obecnie na portalach internetowych. Materiał badawczy podzielono zatem zgodnie z dominującą funkcją: deskryptywną, dyrektywną bądź ekspresywną ${ }^{16}$ (Szylko-Kwas, 2019, s. 89-90).

\section{WYNIKI BADAŃ}

Zaczynając od danych liczbowych, warto wskazać, że tematyka ukraińska cieszyła się stałym zainteresowaniem przez cały 2019 rok (por. rysunek 1). Liczba wypowiedzi medialnych z leksemem „Ukrainiec” wyniosła łącznie 69. Średnio w jednym miesiącu publikowano około sześciu tekstów, poruszających tę problematykę, a mediana liczby tekstów wyniosła 4. Wyjątkowe były pod tym względem jedynie dwa miesiące: sierpień oraz listopad, kiedy odnotowano aż 13 artykułów. Pierwszy z wymienionych terminów mógłby wskazywać na chęć skupienia uwagi odbiorców także podczas wakacji, czyli w okresie, gdy rzeczywistość społeczno-polityczna nie obfituje zwykle w ważne wydarzenia. Potwierdza to rozmaitość tematów, jakie poruszano wówczas na portalu w kontekście Ukraińców. Z kolei w listopadzie, oprócz wzmianek dotyczących zdarzeń kryminalnych (które pojawiały się w każdym miesiącu), trzykrotnie omawiano wysokość zarobków pracowników z Ukrainy, a także zwycięstwo Ukraińca w pierwszym Wrocławskim Biegu Niepodległości.

16 Szczegółowe dane na ten temat przedstawiono w dalszej części artykułu. 


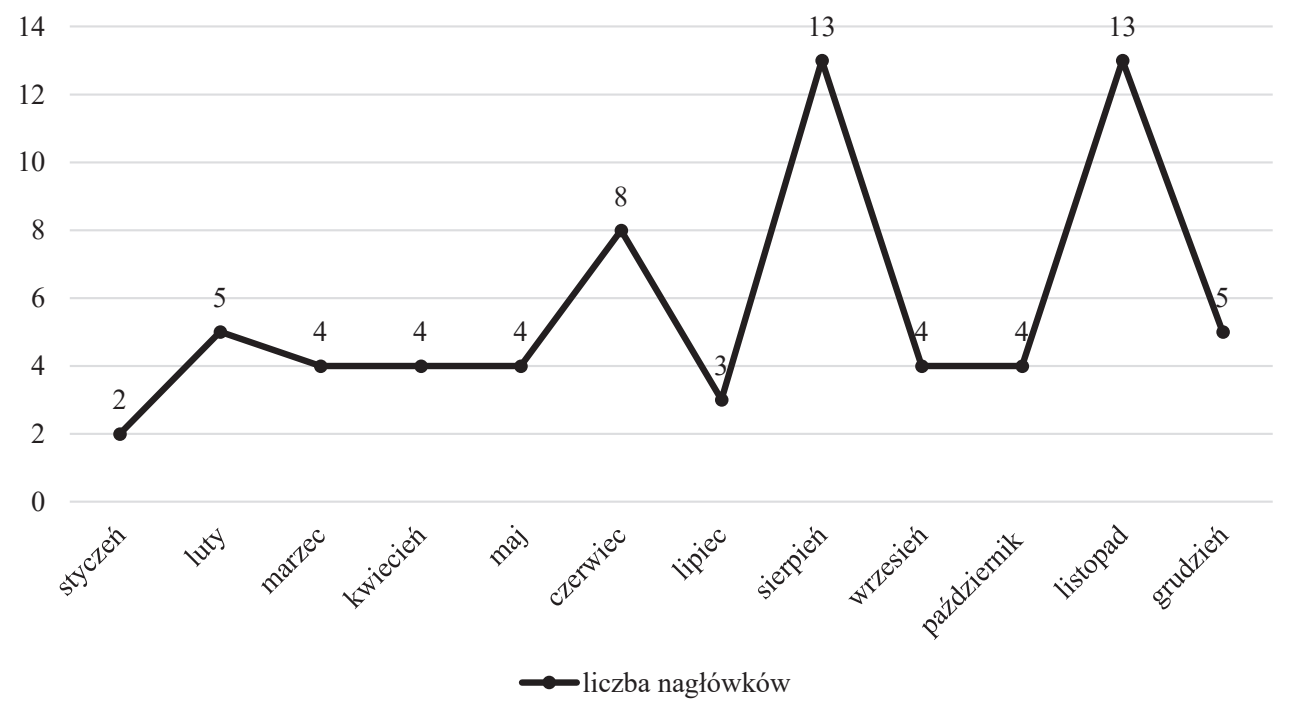

Rysunek 1. Liczba wypowiedzi medialnych z leksemem „Ukrainiec” na portalu „Gazety Wrocławskiej” w poszczególnych miesiącach 2019 roku, $N=69$

Przeciętna długość nagłówków wyniosła 83 znaki ze spacjami, co potwierdza dążenie do skrótowości oraz szybkości przekazu (por. Sadowska, 2007, s. 401-413; Ślawska, 2008, s. 117-126). Zważywszy na to, że 70\% nagłówków składało się z dwóch wypowiedzeń, rola doprecyzowujących podtytułów zdaje się jeszcze istotniejsza. Poniżej zaprezentowano kilka przykładów, w których wzmianka o udziale Ukraińców pojawiła się dopiero w drugiej części nagłówka:

„Napad na bank we Wrocławiu. Obława na Ukraińców”17,

„Wypadek na Robotniczej. Ukrainiec wjechał w latarnię (ZDJĘCIA)”,

„Bmw wjechało w pieszych. Troje Ukraińców nie żyje”,

„Śmiertelny wypadek w LG pod Wrocławiem. Nie żyje Ukrainiec”.

Do badania dominujących funkcji nagłówków wykorzystano typologię Joanny Szylko-Kwas (2019). W rezultacie nagłówki podzielono na trzy grupy, zgodnie z ich dominującą funkcją (deskryptywną, dyrektywną lub ekspresywną). Wyniki prezentuje tabela 1.

17 Wszystkie cytowane nagłówki pochodzą z badanego portalu www.gazetawroclawska.pl. Ze względu na ograniczone rozmiary artykułu oraz mając na uwadze jego przejrzystość, zdecydowano się zrezygnować z odesłań do wypowiedzi medialnych, których nagłówki analizowano. Zainteresowanych wglądem do całego korpusu, autorka prosi o kontakt. 
Tabela 1. Funkcje nagłówków wypowiedzi medialnych z leksemem „Ukrainiec” na portalu „Gazety Wrocławskiej” w 2019 roku

\begin{tabular}{|l|c|c|c|}
\hline Funkcja naglówków & deskryptywna & dyrektywna & ekspresywna \\
\hline Liczba nagłówków & 31 & 2 & 36 \\
\hline $\begin{array}{l}\text { Procentowy udział w materiale } \\
\text { badawczym [\%] }\end{array}$ & 45 & 3 & 52 \\
\hline
\end{tabular}

Ponad połowa analizowanych nagłówków pełniła funkcję ekspresywną, co może świadczyć o dużej emocjonalności przekazów medialnych oraz o wykorzystywaniu szokujących treści w celu skupienia uwagi odbiorcy. Ekspresywne nagłówki odnosiły się przede wszystkim do zdarzeń kryminalnych oraz wypadków (często tragicznych w skutkach). Ekspresję wzmacniały także cytowane wypowiedzi bohaterów, wulgaryzmy i zaskakujące liczby, na przykład:

„Klient Biedronki do ochroniarza-Ukraińca:»Wyp... z Polski, jeb... czarnuchu«. Grozi mu więzienie”, „W SUV-ie pędził blisko $150 \mathrm{~km} / \mathrm{h}$ przez most Milenijny. To Ukrainiec spieszył się na spotkanie... (NAGRANIE)",

„Tragedia w Zamku Książ. Ukrainiec rzucił się z dziedzińca kilkanaście metrów w dół”.

Deskryptywne nagłówki skrótowo opisywały zaistniałe zdarzenia, a podstawę dla nich stanowiły często dane statystyczne bądź działania ze sfery kultury. Nawet jeśli wspominano o wypadku, to informowano tylko o jego miejscu lub prawdopodobnej przyczynie, nie wskazując na narodowość sprawcy bądź ofiary, na przykład:

„O tym, że Ukraińcy wiążą przyszłość z naszym krajem świadczy większa skłonność do zakładania rodziny",

„Wypadek na drodze S5 pod Trzebnicą. Rynny na drodze”,

„Przyjęte przez niemiecki parlament regulacje prawne nie spowodują masowych wyjazdów Ukraińców z Polski”.

Bardzo rzadko można było natomiast natrafić na dyrektywne nagłówki. W badanym okresie pojawiły się tylko dwa tego typu przykłady. Oba zachęcały odbiorcę do obejrzenia galerii zdjęć (a tym samym wygenerowania większej liczby kliknięć, poprawiających statystyki strony internetowej dla reklamodawców). Sygnalizując jedynie zagadnienie, tworzyły one lukę poznawczą (ang. curiosity gap), a w swej formie zbliżały się do stylistyki clickbaitu (por. Lisowska-Magdziarz, 2019, s. 23-24):

„Kupować mieszkanie czy poczekać na spadek cen? Zobacz, co czeka nas na rynku nieruchomości w 2020 roku”,

„Potrafią przeżyć za 200-500 zł miesięcznie. Zobacz, ile zarabiają Ukraińcy w Polsce”. 
Przedstawiona wyżej typologia dominujących funkcji nagłówków łączy się również z popularnymi obszarami tematycznymi, którymi były: zagadnienia pracownicze, zdarzenia kryminalne oraz wypadki. Rzadziej pojawiały się wzmianki na temat wydarzeń kulturalnych, sportowych bądź politycznych. Udział poszczególnych kategorii tematycznych prezentuje rysunek 2 .

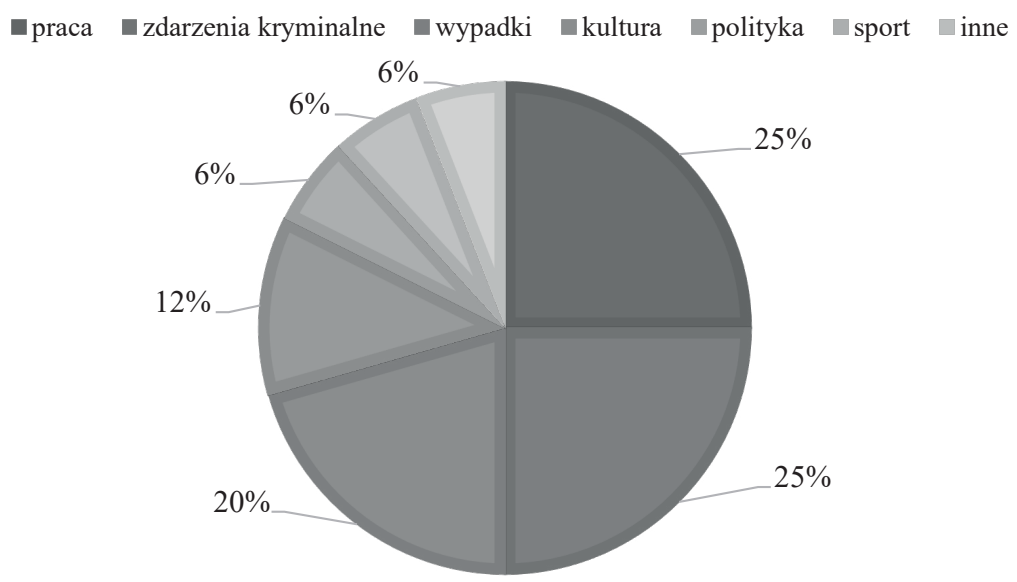

Rysunek 2. Kategorie tematyczne nagłówków wypowiedzi medialnych z leksemem „Ukrainiec” na portalu „Gazety Wrocławskiej” w 2019 roku, $N=69$

Przywołane przez dziennikarzy zdarzenia kryminalne podzielić można na takie, w których ofiarą był Ukrainiec (9 nagłówków) oraz takie, podczas których obywatel Ukrainy działał jako sprawca (8 nagłówków). Niemal równy rozkład omawianych wydarzeń może świadczyć o ambiwalentnym wizerunku Ukraińców, których portal „Gazety Wrocławskiej” czasem przedstawia jako skłonnych do bójek, gotowych do złamania prawa, a innym razem - narażonych na ataki Polaków, na przykład:

„Maksym S. zatrzymany przez ABW. Ukrainiec planował zamach w Puławach, chciał zdetonować samochód pułapkę przed galerią handlową",

„Prokurator: Taksówkarz z Wrocławia usiłował zabić Ukraińca na rowerze. Grozi mu dożywocie”,

„Zabójstwo w mieszkaniu. Ukrainiec zginął od ciosu nożem”.

Druga równie popularna kategoria tematyczna objęła zagadnienia związane z pracą świadczoną przez Ukraińców, a spoglądając z szerszej perspektywy - z sytuacją gospodarczą Polski uzależnioną od liczby pracujących migrantów. W tym kontekście obecność Ukraińców na Dolnym Śląsku oceniano zwykle pozytywnie - jako wsparcie dla polskich przedsiębiorstw i systemu emerytalnego. Wzmianki negatywne odnosiły się natomiast do nielegalnego zatrudniania ukraińskich pracowników bądź ich wygórowanych roszczeń płacowych. Dziennikarze 
straszyli też prognozowaną ucieczką Ukraińców na Zachód i pogarszającą się sytuacją Zakładu Ubezpieczeń Społecznych, na przykład:

„Ukraińcy będą ratować nasz system emerytalny? Emilewicz: Na razie nie ma powodów mówić o ratowaniu systemu emerytalnego",

„Ukraińcy chcą zarabiać więcej od Polaków. Mogą liczyć nawet na 21 zł brutto za godzinę [Wideo, GALERIA]",

„Ukraińcy pracowali na lewo na budowie w centrum Wrocławia”.

Trzecią najpopularniejszą kategorią tematyczną były wypadki. Wzmianki dotyczyły przede wszystkim zdarzeń drogowych. Sprawców, oprócz brawurowej jazdy, wyróżniał też często spożyty wcześniej alkohol. Do kategorii wypadków zaliczono również tragiczne w skutkach zdarzenia, których przyczyn wciąż nie poznano:

„Ciało Ukraińca odnalezione pod Skokami. Prokuratura wciąż czeka na wyniki sekcji zwłok”,

„Wypadek dwóch samochodów osobowych na Psim Polu. Ukrainiec w BMW nie ustąpił pierwszeństwa",

„Pijany Ukrainiec spowodował wypadek pod Długołęką. Dwie osoby ranne”.

\section{ŚRODKI JĘZYKOWE SŁUŻĄCE TWORZENIU DYCHOTOMII SWÓJ-OBCY ORAZ STEREOTYPIZACJI}

Kolejnym interesującym elementem narracji na temat Ukraińców były rozmaite środki językowe, wzbogacające medialne przekazy. Do najczęstszych należały pytania retoryczne, mające również potencjał clickbaitowy. Pytania miały skłonić odbiorcę do namysłu oraz poszukiwania odpowiedzi w dalszej części publikacji, a niekiedy przestrzegały również przed możliwymi konsekwencjami przewidywanych wydarzeń, na przykład:

„Ukraińcy niedługo wyjadą z Polski? Szykuje się bój o pracowników. Lepsze warunki Ukraińcom oferują Czesi i Niemcy [14 czerwca 2019]",

„ZUS sfinansuje emerytury Ukraińców? Kilka lat w Polsce i już można pobierać u nas emerytury tak donoszą media. Ile w tym prawdy? [30.10.]”,

„Biznesmen z piorunem i Ukraińcy. Kto zapłaci za rozbrojenie ekobomby?”

Ostatni z przywołanych nagłówków zawiera w sobie jeszcze intrygujący neologizm (,ekobomba”), który - kojarząc się z czymś bardzo niebezpiecznym - może silnie oddziaływać na uczucia czytelnika.

Spośród innych środków językowych warto wymienić także emocjonalne cytaty - zarówno polityków, jak i osób bliżej nieznanych, odpowiadających przed sądem za agresję słowną, na przykład: 
„Klient Biedronki do ochroniarza-Ukraińca: »Wyp... z Polski, jeb... czarnuchu«. Grozi mu więzienie",

„Janusz Korwin-Mikke: Gdybym był ruskim agentem, to mówiłbym, że Rosję trzeba zniszczyć. Rząd PiS nie umie prowadzić polityki międzynarodowej”.

Pierwszy z przytoczonych przykładów jest szczególnie wyrazisty, ponieważ wrogość odnosi się także do koloru skóry, który pełni tutaj funkcję metafory. Ochroniarz, który usłyszał tę obelgę, nie był bowiem osobą czarnoskórą, a sformułowanie to miało najprawdopodobniej przede wszystkim podkreślić jego obcość oraz imputowane przez agresora zacofanie, opóźnienie cywilizacyjne.

Opozycję swój-obcy tworzyły również inne nagłówki z wartościującymi sformułowaniami, ze słowami o silnie negatywnym nacechowaniu emocjonalnym oraz z metaforami, na przykład:

„W domu powstał ukraiński hotel pracowniczy. Życie sąsiadów zamieniło się w koszmar”,

„Ukraińska rodzina po czterech latach wyrzucona z Polski. Sąsiedzi piszą do prezydenta”,

„ZUS: Dolny Śląsk zagłębiem Ukraińców. Więcej jest ich tylko w stolicy”.

Medialny przekaz dynamizowały z kolei konstrukcje wyzerowane z czasownika oraz kolokwializmy:

„Ukraińcy pracowali na lewo na budowie w centrum Wrocławia”,

„Napad na bank we Wrocławiu. Obława na Ukraińców”,

„Polska coraz mniej atrakcyjna dla Ukraińców”.

Za pomocą aplikacji webowej Korpusomat (Kieraś et al., 2018, s. 21-27) wygenerowano ponadto listę lematów o najwyższej frekwencji (tabela 2).

Tabela 2. Lista frekwencyjna obejmująca lematy występujące co najmniej pięć razy w nagłówkach wypowiedzi medialnych z leksemem „Ukrainiec” na portalu „Gazety Wrocławskiej” w 2019 roku

\begin{tabular}{|l|c|c|}
\hline \multicolumn{1}{|c|}{ Lemat } & Część mowy & Frekwencja \\
\hline Wrocław & rzeczownik & 8 \\
\hline Polska & rzeczownik & 7 \\
\hline wypadek & rzeczownik & 5 \\
\hline Ukraina & rzeczownik & 5 \\
\hline Polak & rzeczownik & 8 \\
\hline
\end{tabular}

Źródło: badania własne z wykorzystaniem aplikacji webowej Korpusomat 
Popularne lematy korespondują z omówionymi wyżej kategoriami tematycznymi (wypadki, zagadnienia pracownicze), a jednocześnie potwierdzają istotną rolę dookreślania przez dziennikarzy regionalnych miejsca opisywanych wydarzeń (Wrocław, Dolny Śląsk, Polska, Ukraina) oraz ich uczestników (Ukrainiec, Polak).

Tworzona w ten sposób opowieść medialna nie jest bynajmniej wolna od stereotypów, tj. generalizacji oraz sądów wartościujących, które polegają na przypisywaniu wszystkim członkom wybranej grupy społecznej określonego zbioru cech, tworzącego jej homogeniczny obraz (por. Błuszkowski, 2003; Bokszański, 2001; Skibińska, 2020b i wskazana tam literatura). Jak pisze Krzysztof Jurek: „Dzięki stereotypom świat staje się bardziej konkretny i zrozumiały, a abstrakcyjne, złożone pojęcia ulegają uproszczeniom. Skomplikowana rzeczywistość społeczna sprowadzana zostaje do jednoznacznych, niepodważalnych i zrozumiałych faktów" (Jurek, 2019, s. 31).

Przeprowadzona analiza pozwala stwierdzić, że dziennikarze „Gazety Wrocławskiej” powielają stereotypy dotyczące Ukraińców, co może mieć potencjał kształtujący wobec stosunku odbiorców ich treści do migrantów. W literaturze wskazuje się, że historyczne uwarunkowania (m.in. konflikty narodowościowe w XX wieku, wieloletnia przynależność Ukrainy do negatywnie waloryzowanej Rosji) sprawiają, iż stereotyp Ukraińca jest w Polsce negatywny (por. Jurek, 2019; Tazbir, 1991). Zdaniem Renaty Radzkiej, Ukraińca kojarzymy stereotypowo z bandytą, gwałcicielem, barbarzyńcą, anarchistą, handlarzem ulicznym lub nielegalnym pracownikiem (2006, s. 167-177). Inne stereotypowe atrybuty Ukraińców to m.in.: zacofanie, ubóstwo, lenistwo, niegospodarność, alkoholizm, nieżyczliwość, mściwość, bezwzględność, podstępność, nacjonalizm, brak poszanowania dla prawa, kłótliwość (Bartmiński, 2007; Błuszkowski, 2003; Walas, 1995). Jak zauważa Jan Błuszkowski, już samo usytuowanie Ukrainy na wschód od Polski przyczynia się do stosowania pewnych uproszczeń, przejawiających się między innymi w poczuciu wyższości Polaków (wynika to m.in. z pozytywnej waloryzacji Zachodu oraz negatywnej - Wschodu, por. Błuszkowski, 2003, s. 224-225). W tabeli 3 uporządkowano stereotypy dotyczące Ukraińców, dostrzeżone $\mathrm{w}$ materiale badawczym.

Tabela 3. Stereotypy dotyczące Ukraińców w nagłówkach wypowiedzi medialnych z leksemem „Ukrainiec” na portalu „Gazety Wrocławskiej” w 2019 roku

\begin{tabular}{|l|c|}
\hline \multicolumn{1}{|c|}{ Stereotyp } & $\begin{array}{c}\text { Liczba } \\
\text { wystąpień }\end{array}$ \\
\hline Ukrainiec - poszukiwany pracownik lub student (pozytywnie, wsparcie dla ZUS) & 14 \\
\hline $\begin{array}{l}\text { Ukrainiec - brawurowy, impulsywny kierowca, powodujący wypadki } \\
\text { (często pod wpływem alkoholu) }\end{array}$ & 8 \\
\hline Ukrainiec - ofiara nietolerancyjnego Polaka & 7 \\
\hline Ukrainiec - przestępca (bezwzględność, brak poszanowania dla prawa) & 6 \\
\hline Ukrainiec - roszczeniowy pracownik & 2 \\
\hline Ukrainiec - ofiara bezdusznej polskiej administracji & 1 \\
\hline
\end{tabular}


Łącznie zauważono 38 nagłówków ze stereotypami, co oznacza, że ponad połowa korpusu (55\%) bazuje na schematycznej interpretacji rzeczywistości. W 2019 roku „Gazeta Wrocławska" najczęściej (czternastokrotnie) odwoływała się do pozytywnego stereotypu Ukraińca, opisując migranta zza Buga jako zaradnego, sumiennego pracownika, który może wspomóc polski system ubezpieczeń społecznych. Warto jednak podkreślić, że zawody wykonywane przez migrantów ze Wschodu nie cieszą się raczej autorytetem społecznym i polegają głównie na pracy fizycznej:

„Biedronka kusi pracowników z Ukrainy [ZAROBKI]”,

„Czterej Ukraińcy za trzy miesiące pracy na budowie dostali po 1300 zł, Ukraińcy niedługo wyjadą z Polski? Szykuje się bój o pracowników. Lepsze warunki Ukraińcom oferują Czesi i Niemcy [14 czerwca 2019]".

Dokonana analiza prowadzi do wniosku, że o ile dziennikarzy wrocławskiego portalu cieszy praca Ukraińców w nisko płatnych (niechętnie wykonywanych przez Polaków) zawodach, o tyle obawiają się oni konkurencji migrantów w walce o wyższe zarobki:

„Ukraińcy chcą zarabiać więcej od Polaków. Mogą liczyć nawet na 21 zł brutto za godzinę [Wideo, GALERIA]",

„ZUS sfinansuje emerytury Ukraińców? Kilka lat w Polsce i już można pobierać u nas emerytury tak donoszą media. Ile w tym prawdy? [30.10.]”.

Stereotypem, który często gościł na łamach witryny „Gazety Wrocławskiej”, był też stereotyp Ukraińca - brawurowego kierowcy, sprawcy wypadków drogowych. Jako domniemane przyczyny tych zdarzeń dziennikarze wskazywali głównie spożyty wcześniej alkohol bądź impulsywność, na przykład:

„Pijany Ukrainiec spowodował wypadek pod Długołęką. Dwie osoby ranne”.

Kolejną perspektywą, wokół której koncentrowały się stereotypowe ujęcia migrantów były akty agresji i przestępstwa - zarówno te, których sprawcami byli Ukraińcy (sześciokrotnie), jak i takie, podczas których to oni padali ofiarą nietolerancyjnych zachowań Polaków (siedmiokrotnie). Przestępstwa dokonywane przez Ukraińców miały niekiedy charakter rabunkowy, związany z chęcią wzbogacenia się (co potwierdzać może stereotyp pazernego Ukraińca):

„Trzech Ukraińców próbowało okraść bankomat w Tesco",

„Napad na bank we Wrocławiu. Obława na Ukraińców”.

Inne nagłówki wskazywały na skłonność do kłótni oraz bójek, wyróżniającą tak Polaków, jak i Ukraińców:

„Zabójstwo w mieszkaniu. Ukrainiec zginął od ciosu nożem”,

„Zaatakował Ukraińców, bo rozmawiali w swoim języku”. 


\section{WNIOSKI}

Podsumowując, obraz Ukraińców dostrzeżony w analizowanych nagłówkach portalu „Gazety Wrocławskiej” odpowiada trzem dominującym wizerunkom migrantów, wymienionym przez Ignacego Jóźwiaka, Joannę Konieczną-Sałamatin oraz Michała Tudorowskiego (2009, s. 31-34) - migrantów jako szansy (przede wszystkim na rozwój gospodarczy Polski), migrantów jako ofiary oraz jako zagrożenia (m.in. przestępczością czy psuciem rynku pracy). Medialna narracja zdaje się zatem prowadzona z perspektywy „polskocentrycznej” (a ściślej - „dolnośląskocentrycznej”). Dziennikarze na konkretnych (nierzadko szokujących) przykładach starają się unaocznić czytelnikom, co w życiu regionu zmienia obecność migrantów. Stosunkowo krótkie, ekspresywne nagłówki miały przykuć uwagę odbiorców, a wzmianki na temat zdarzeń kryminalnych - zapaść w pamięci na dhużej.

Spośród wskazanych przez Lisowską-Magdziarz (2019, s. 23-24) cech clickbaitowania w materiale badawczym zauważono przede wszystkim silną retoryczność nakierowaną na nawiązanie kontaktu z czytelnikiem lub jego emocjonalne pobudzenie, zamiast na dostarczenie informacji (por. pytania retoryczne, emocjonalne cytaty, wulgaryzmy - dominacja ekspresywnej funkcji nagłówka). Ponadto, clickbaitowy był dobór tematyki - duży udział zagadnień związanych ze zbrodniami, przestępstwami, aktami przemocy oraz wypadkami. Dostrzeżone rozwiązania językowe, jakie uznać można za charakterystyczne dla clickbaitowych wypowiedzi medialnych, to także wyrażenia o skrajnym nacechowaniu emocjonalnym (zwłaszcza negatywnym), kolokwializmy, wulgaryzmy, pytania retoryczne oraz niedopowiedzenia. Z innych istotnych elementów tworzących medialną narrację na temat Ukraińców, wspomnieć należy o częstym wskazywaniu narodowości sprawcy lub ofiary.

W tym kontekście warto przywołać słowa Joanny Bieleckiej-Prus: „,...] to, w jaki sposób mówi się i pisze o jednostkach i zbiorowościach, nadając im określone znaczenia, wpływa na funkcjonujące w społeczeństwie wyobrażenia, a w rezultacie działania wobec nich" $(2020$, s. 183).

Medialna agenda kształtować więc może przedmiot zainteresowań odbiorców, inspirować toczone przez nich dyskusje, a w konsekwencji - wzmacniać konkretną wizję świata, przejawiającą się między innymi w stosunku do migrantów (bliższych lub dalszych, zależnie od waloryzacji i sposobu opisu). Jak wskazuje Alisa Borkowska: ,,[... ] językowy obraz Ukraińca jest częścią językowego obrazu świata Polaków, a prowadzone na ten temat badania wspomagają zrozumienie świadomości zbiorowej oraz wypracowanie technik komunikacji międzykulturowej" (2020, s. 98).

Warto wspomnieć, że niektórzy nadawcy medialni ${ }^{18}$ wdrażają konkretne strategie, mające na celu dążenie do przestrzegania zasad grzeczności językowej, przeciwdziałanie mowie nienawiści, oraz propagowanie poprawności politycznej (por. Grabicz-Stodolna, 2020) - między innymi niepublikowanie danych o narodowości sprawcy, gdy taka informacja jest zbędna z punktu widzenia celu przekazu, a wywołać może silne społeczne emocje lub napiętnowanie przedstawicieli mniejszości. Dobre praktyki dziennikarskie znajdują również

18 Por. https://www.agora.pl/raportCSR-2017/etyka-i-przeciwdzialanie-naduzyciom oraz https://reporterzy.info/147,kodeks-etyki-dziennikarskiej-stowarzyszenia-dziennikarzy-polskich.html [8.08.2021]. 
wyraz w przyjętych przez redakcje kodeksach etycznych oraz wewnętrznych procedurach, usprawniających monitoring treści zamieszczanych przez odbiorców (np. niezwłoczne usuwanie wulgarnych komentarzy, naruszających dobra osobiste innych osób). Wydaje się, że opisane wyżej działania mogą stanowić skuteczną odpowiedź na dostrzeżoną w analizowanych nagłówkach stereotypizację Ukraińców (a także szerzej, wszelkich mniejszości - por. Ulita, 2012; Drożdż, 2019).

Konkludując, w ponowoczesnym świecie podział na swoich i obcych nie jest dany raz na zawsze. W odmiennych sytuacjach, w obrębie różnych grup ten sam człowiek może się niekiedy jawić jako swój, innym razem - jako obcy: „[...] Obcość stała się uniwersalna. Ale jeśli każdy jest po trosze obcym, nie jest nim w pełni nikt” (Bauman, 1995, s. 137). Tezę tę potwierdzają analizowane nagłówki, które jednego dnia przedstawiają Ukraińców jako realne zagrożenie dla bezpieczeństwa rodzimych pracowników czy uczestników ruchu drogowego, zaś nazajutrz - jako szansę na rozwój regionu i zwiększenie jego konkurencyjności.

\section{BIBLIOGRAFIA}

Balcerzak, A., Gackowski, T. (2009). Analiza zawartości. W: T. Gackowski, M. Łączyński (red.), Metody badania wizerunku w mediach. Czym jest wizerunek. Jak i po co należy go badać (s. 17-32). Warszawa: CeDeWu.

Baran, D. (2016). Wizerunek Ukraińców na łamach wybranej polskiej prasy. Państwo i Spoteczeństwo, 1, 16, 98-116.

Bartmiński, J. (2007). Stereotypy mieszkają w języku: studia etnolingwistyczne. Lublin: Wydawnictwo Uniwersytetu Marii Curie-Skłodowskiej.

Bauman, Z. (1995). Wieloznaczność nowoczesna, nowoczesność wieloznaczna. Warszawa: Wydawnictwo Naukowe PWN.

Benedyktowicz, Z. (2000). Portrety „,Obcego”. Od stereotypu do symbolu. Kraków: Wydawnictwo Uniwersytetu Jagiellońskiego.

Bielecka-Prus, J. (2020). Obraz imigrantek z Ukrainy w polskim dyskursie prasowym. Studia Migracyjne - Przeglad Polonijny, 2, 176, 177-200.

Bokszański, Z. (2001). Stereotypy a kultura. Wrocław: Fundacja na Rzecz Nauki Polskiej-Leopoldinum.

Borkowska, A. (2020). Językowy obraz Ukraińców w polskich dziennikach prasowych (analiza materiałów Narodowego Korpusu Języka Polskiego z lat 2005-2010). Acta Polono-Ruthenica, 3, 25, 91-108.

Błuszkowski, J. (2003). Stereotypy narodowe w świadomości Polaków. Warszawa: Dom Wydawniczy ELIPSA.

Brenda-Mańkowska, A. (2019). Fake news, clickbait, żebrolajki - problemy mediów w dobie postprawdy. W: V. Tanaś, W. Welskop (red.), Mass media we wspótczesnym świecie (s. 11-20). Łódź: Wydawnictwo Naukowe Wyższej Szkoły Biznesu i Nauk o Zdrowiu.

Guzik, B. (2008). Obcy... Inny... wśród swoich w wybranych nowelach pozytywistycznych. Annales Academiae Paedagogicae Cracoviensis. Studia Historicolitteraria, 8, 36-43. 
Cymanow-Sosin, K., Drąg, K. (2017). Obraz ekonomicznej migracji Ukraińców do Polski w nowych mediach - zróżnicowane formy zagrożenia w tekstach polskojęzycznych. Kultura - Media - Teologia, 29, 58-68.

Cyrek, B. (2020). YouTube jako serwis społecznościowy - w stronę klasyfikacji witryny. Zarzadzanie Mediami, 2, 8, 119-136.

Dobek-Ostrowska, B. (2009). Porozumienie czy konflikt? Politycy, media i obywatele w komunikowaniu politycznym. Warszawa, Bielsko-Biała: Wydawnictwo Szkolne PWN.

Drożdż, M. (2019). Ile jest etyki w kodeksach etyki dziennikarskiej - specyfika kodeksów etycznych. Rocznik Medioznawczy, 1, 21-35.

Furman, W. (2006). Nagłówek. W: W. Pisarek (red.), Słownik terminologii medialnej (s. 127). Kraków: Universitas.

Furman, W. (2006). Tytuł. W: W. Pisarek (red.), Słownik terminologii medialnej (s. 225). Kraków: Universitas.

Gackowski, T., Łączyński, M. (red.). (2009). Metody badania wizerunku w mediach. Czym jest wizerunek. Jak i po co należy go badać. Warszawa: CeDeWu.

Golińska-Konecko, M. (2020). Problematyka ukraińska w programie „Ukraińskie wieści” w TVP Olsztyn w latach 2005-2015. Civitas et Lex, 1, 25, 28-39.

Górny, A., Kołodziejczyk, K., Madej, K., Kaczmarczyk, P. (2019). Nowe obszary docelowe w migracji z Ukrainy do Polski. Przypadek Bydgoszczy $i$ Wrocławia na tle innych miast. Warszawa: Fundacja Ośrodek Badań nad Migracjami.

Grabicz-Stodolna, D. (2020). Doświadczenie politycznej poprawności a grzeczność językowa. Dziennikarstwo i Media, 13, 67-75.

Grzymała-Kazłowska, A. (2007). Konstruowanie ,,innego”: wizerunki imigrantów w Polsce. Warszawa: Wydawnictwo Uniwersytetu Warszawskiego.

Jóźwiak, I., Konieczna-Sałamatin, J., Tudorowski, M. (2009). „,Bez cudzoziemców bylibyśmy ubożsi”. Wizerunek obcokrajowców na łamach polskiej prasy. Warszawa: Instytut Spraw Publicznych.

Jura, J., Kałużyńska, K. (2015). Obraz obcokrajowców i imigrantów w polskich mediach tradycyjnych i internetowych. W: J. Konieczna-Sałamatin (red.), Imigranci o wysokich kwalifikacjach na polskim rynku pracy (s. 2-52). Warszawa: Instytut Społeczno-Ekonomicznych Ekspertyz, Fundacja „Nasz Wybór”.

Jurek, K. (2019). Stereotypy na temat Ukraińców funkcjonujące w Polsce. W: M. Lubicz Miszewski (red.), Imigranci z Ukrainy w Polsce. Potrzeby i oczekiwania, reakcje społeczne, wzywania dla bezpieczeństwa (s. 31-42). Wrocław: Wydawnictwo AWL.

Kieraś, W., Kobyliński, Ł., Ogrodniczuk, M. (2018). Korpusomat - a tool for creating searchable morphosyntactically tagged corpora. Computational Methods in Science and Technology, 1, 24, 21-27.

Konieczna-Sałamatin, J. (2001). Polska-Ukraina: wzajemny wizerunek. Warszawa: Instytut Spraw Publicznych.

Krzeszowski, T. (1999). Aksjologiczne aspekty semantyki językowej. Toruń: Wydawnictwo Uniwersytetu Mikołaja Kopernika.

Lisowska-Magdziarz, M. (2019). Identyfikacja i analiza clickbaitów w informacyjnych tekstach dziennikarskich - rekonesans metodologiczny. W: A. Hess, M. Nowina-Konopka, 
W. Świerczyńska-Głownia (red.), Dynamika przemian $w$ mediach (s. 15-36). Kraków: Wydawnictwo Uniwersytetu Jagiellońskiego.

Lubicz Miszewski, M. (red.). (2018). Imigranci z Ukrainy w Polsce. Potrzeby i oczekiwania, reakcje społeczne, wyzwania dla bezpieczeństwa. Wrocław: Wydawnictwo AWL.

Maj, A. (2013). Analiza treści. W: M. Makowska (red.), Analiza danych zastanych. Przewodnik dla studentów (s. 127-147). Warszawa: Wydawnictwo Naukowe Scholar.

Malinowski, B. (2016). Jak Facebook zamyka nas w bańce informacyjnej. Algorytm filtrujący newsfeed a zjawisko filter buble. Zarzadzanie Mediami, 1, 4, 15-22.

Nowak, E. (2009). Komercjalizacja komunikacji politycznej - infotainment i politainment w programach informacyjnych. Annales Universitatis Mariae Curie-Skłodowska, 16, 207-208.

Omyła-Rudzka, M. (oprac.). (2021). Stosunek do innych narodów. Komunikat z badań CBOS, nr 30/2021.

Pałuszyńska, E. (2016). Zmiany w językowej formie nagłówków prasowych. Rozprawy Komisji Językowej ŁTN, 62, 103-115.

Piekot, T. (2006). Dyskurs polskich wiadomości prasowych. Kraków: Universitas.

Pisarek, W. (1983). Analiza zawartości prasy. Kraków: Ośrodek Badań Prasoznawczych.

Prokop, M. (2013). Stereotyp Ukraińca w polskim tygodniku „Polityka” oraz stereotyp Polaka na łamach „Dzerkało Tyżnia. Ukraina”. Warmińsko-Mazurski Kwartalnik Naukowy, Nauki Społeczne, 3, 47-66.

Radzka, R. (2006). Wizerunek Ukraińca w prasie polskiej na wybranych przykładach. Medialna struktura stereotypu narodowego. W: A. Naruszewicz-Duchlińska, M. Rutkowski (red.), Nowe zjawiska w języku, tekście i komunikacji (s. 167-177). Olsztyn: Zakład Poligraficzny UWM.

Rozbicka, P. (2020). Inny w świecie Innego. Komunikacja, adaptacja, uchodźstwo. Wrocław: Oficyna Wydawnicza ATUT.

Rozbicka, R. (2018). Imigrant czy uchodźca? Wizerunek Ukraińców mieszkających w Polsce na podstawie tygodników opiniotwórczych: „Do Rzeczy”, „Newsweek Polska” i „Tygodnik Powszechny" w latach 2014-2016. W: M. Lubicz Miszewski (red.), Imigranci z Ukrainy $w$ Polsce. Potrzeby $i$ oczekiwania, reakcje społeczne, wyzwania dla bezpieczeństwa (s. 43-59). Wrocław: Wydawnictwo AWL.

Sadowska, A. (2007). Tytuły prasowe - ich budowa i funkcja. Acta Universitatis Lodziensis Folia Litteraria Polonica, 9, 401-413.

Skibińska, A. (2020a). Ukraińcy w prasie regionalnej Dolnego Śląska. Com.press, 1, 3, 54-77.

Skibińska, A. (2020b). Stereotyp Ukraińca w polskiej elektronicznej prasie regionalnej. W: M. Śliwa, M. Maciąg (red.), Nauki społeczne jako przedmiot badań naukowych. Ujęcie interdyscyplinarne (s. 7-23). Lublin: Wydawnictwo Naukowe TYGIEL.

Sojka-Masztalerze, H. (2004). Rusini czy Ukraińcy? Językowy obraz nacji ukraińskiej w prasie polskiej (1918-1939). Wrocław: Wrocławskie Towarzystwo Naukowe.

Szylko-Kwas, J. (2019). Fotografia jako wypowiedź dziennikarska - odmiany gatunkowe. Studia Medioznawcze, 1, 76, 83-98.

Szynol, A. (2014). Multimedialny kombajn - status współczesnego dziennikarza. Gospodarka, Rynek, Edukacja, 3, 15, 21-29. 
Ślawska, M. (2008). Tytuł - najmniejszy tekst prasowy. Roczniki Prasoznawcze, 2, 117-126. Tazbir, J. (red.). (1991). Mity i stereotypy w dziejach Polski. Warszawa: Wydawnictwo Interpress.

Troszyński, M. (2016). Wizerunek mniejszości w polskich mediach społecznościowych. Warszawa: Fundacja Wiedza Lokalna.

Troszyński, M. (2018). Ukraina i Ukraińcy w polskim dyskursie internetowym. Analiza jakościowo-ilościowa tekstów zamieszczanych w mediach społecznościowych. W: P. Tyma (red.), Raport. Mniejszość ukraińska i migranci z Ukrainy w Polsce. Analiza dyskursu (s. 103-157). Warszawa: Związek Ukraińców w Polsce.

Ulita, M. (2012). Sens istnienia dziennikarskich kodeksów etycznych i ich trudna przydatność. Komunikacja Społeczna, 1, 1-15.

Walas, T. (red.). (1995). Narody i stereotypy. Kraków: Międzynarodowe Centrum Kultury. Znaniecki, F. (1990). Współczesne narody. Warszawa: Wydawnictwo Naukowe PWN.

LIFESAVER FOR THE ECONOMY OR THREAT FROM THE EAST?

THE UKRAINIANS IN THE HEADLINES OF "GAZETA WROCŁAWSKA" WEBSITE

The aim of the article was to examine how a regional portal tells the stories about the Ukrainian migrants living in Lower Silesia. The objective of the research was the articles with the headlines in which the lexeme "Ukrainian" is present. The chronological scope covered media statements published on www.gazetawroclawska.pl in 2019. The previous research on the linguistic image of an Ukrainian in the Polish language led to the conclusion that Polish-Ukrainian relations are strongly historically conditioned and often inscribed in a three-part opposition: an Alien - Other - A Local boy. As a result of content analysis, typical headline constructions were decoded, announcing texts about Ukrainians on the website of "Gazeta Wrocławska". The dominant functions of headlines, the linguistic means used there, the lemmas with the highest frequency and the stereotypes were determined. Referring to the issue of familiarity and foreignness and noticing the ethno-stereotypes about the Ukrainians in the analysed media messages, a diversified image of Ukrainian migrants was reestablished - presented as victims, a threat but also an opportunity.

Keywords: image, familiarity, "Gazeta Wrocławska", headline, foreignness, Ukrainians

Zgłoszenie artykułu: 25.06.2021

Recenzje: 27.07 .2021

Rewizja: 9.08 .2021

Akceptacja: 10.08.2021

Publikacja on-line: 30.10 .2021

(C) 2021 Autorka. Jest to publikacja ogólnodostępna, którą można wykorzystywać, rozpowszechniać i kopiować w dowolnej formie zgodnie z licencją Creative Commons CC-BY 4.0 